\title{
Significance of Mitral M-Mode Vp (Velocity Propagation) for Estimating Mitral Valve Area and Severity in Mitral Stenosis
}

\author{
Bertha Gabriela Napitupulu*, Harris Hasan \\ Department of Cardiology and Vascular Medicine, Faculty of Medicine, Universitas Sumatera Utara / Haji \\ Adam Malik General Hospital, Medan, North Sumatera, Indonesia \\ *Corresponding Author: \\ Bertha Gabriela Napitupulu MD.- email: berthanapitupulu@gmail.com \\ Address: Jalan Sei Bengawan Nomor 15, Medan 20121, Phone: +6282165478578
}

Manuscript submitted: October 4, 2018; Revised and accepted: November 25, 2018

\section{ABSTRACT}

Background: Confirming mitral valve area (MVA) by planimetry is one of the standard procedures for assessing mitral stenosis but MVA were frequently need to be confirmed by other echocardiography parameters that only available in sophisticated centers. Our aim was to evaluate the significance of a simple mitral inflow color M-mode velocity propagation (Vp) for estimating MVA and MS severity.

Methods: The best color view of MS jet were taken from apical 4 chamber, the nyquist limit were adjusted for aliasing the central highest velocity, then M-mode were applied to $\mathrm{MV}$ to calculate $\mathrm{Vp}$ by measuring the slope of the blue jet with the first aliasing velocity. MVA,PHT and mean transmitral gradient were analyzed with Pearson correlation and linear regression. Predictive discrimination value of Vp were analyzed by ROC.

Results: Thirty one MS patients had mean MVA planimetry $0.99 \pm 0.35 \mathrm{~cm}^{2}$ and mean $\mathrm{Vp} 64.49 \pm 21.63 \mathrm{~cm} / \mathrm{s}$. Vp that were found to have a strong negative correlation with MVA (Spearman rho $-0.865, p<0.01$ ). Vp had a good predictive discrimination value as from AUC 0.931. Vp were found to have a moderate correlation with MVA by PHT ( Spearman rho $-0.621, p<0.01$ ). Vp more than $55 \mathrm{~cm} / \mathrm{s}$ had $93.8 \%$ sensitivity and $86.7 \%$ specificity to distinguish severe MS.

Conclusions: By making use of the high temporal resolution of M-mode, a simple color Mitral M-Mode Vp were found statistically significant for estimating MVA severity in MS. Interventional decision for MS could also consider Vp for its strong correlation with MVA on MS, especially for helping on targeting moderate to severe MS in rural and limited centers.

Keywords: color Doppler; M-mode; mitral stenosis; velocity propagation 


\section{INTISARI}

Latar Belakang: Penilaian luas permukaan katup mitral (mitral valve area) dengan metode planimetri masih merupakan prosedur standar dalam menilai stenosis mitral, namun sering kali harus dikonfirmasi dengan modalitas ekokardiografi lain yang hanya terdapat pada fasilitas ekokardiografi yang lebih memadai. Tujuan penelitian ini adalah untuk menilai signifikansi dari penggunaan modalitas sederhana dari velocity propagation (Vp) yang dinilai dengan color M-mode, dalam memperikirakan derajat keparahan stenosis mitral.

Metode: Arah jet pada stenosis mitral diambil dari tampilan color apical 4 chamber, kemudian batas nyquist limit disesuaikan untuk mendapat kecepatan aliasing pada bagian tengah jet, lalu kursor M-mode diarahkan pada katup mitral untuk mendapatkan inflow dari kecepatan aliasing pertama yang berwarna biru. $\mathrm{Vp}(\mathrm{cm} /$ detik) didapat dari hasil pengukuran kemiringan garis dari batas warna dengan isovelocity pertama. Nilai MVA, $\mathrm{PHT}$, dan rerata gradien transmitral akan dinilai dan dihubungkan dengan $\mathrm{Vp}$ lewat analisis korelasi Pearson dan regresi linear. Kemampuan Vp dalam menilai stenosis berat akan dinilai dengan ROC.

Hasil: Sebanyak 31 pasien mitral stenosis memiliki nilai rerata MVA planimetri sebesar $0.99 \pm 0.35 \mathrm{~cm}^{2}$ dengan rerata $V p 64.49 \pm 21.63 \mathrm{~cm} / \mathrm{s}$. Vp berkorelasi negatif dan kuat dengan MVA planimetri (Spearman rho $-0.865, p<0.01$ ). Kemampuan Vp sangat baik dalam memprediksi stenosis mitral berat dengan AUC 0.931. Vp memiliki korelasi yang moderat dengan PHT (Spearman rho -0.621, p <0.01). Vp lebih dari $55 \mathrm{~cm} / \mathrm{s}$ memiliki sensitivitas $93.8 \%$ dan spesifisitas $86.7 \%$ yakni pada stenosis mitral berat.

Simpulan: Dengan memanfaatkan resolusi temporal yang baik dari modalitas M-mode, metode velocity propagation (Vp) pada inflow mitral yang dinilai dengan color M-mode didapati signifikan secara statistik dalam memperkirakan derajat keparahan dan MVA pada stenosis mitral. Keputusan intervensi untuk kasus stenosis mitral dapat mempertimbangkan Vp karena korelasinya yang kuat dengan MVA, yakni untuk membantu dalam membedakan diagnosis dan tatalaksana pada kasus stenosis mitral derajat berat pada pusat kesehatan dengan fasilitas yang terbatas.

\section{INTRODUCTION}

Valve stenosis is a common heart disorder and an important cause of cardiovascular morbidity and mortality. ${ }^{1}$ Rheumatic heart disease (RHD) as complication of acute rheumatic fever is still the main cause of the valve stenosis where mitral stenosis (MS) is the most frequent valve stenosis to be found. It is found mainly on the developing country when $79 \%$ of its majority patients are living, which can be counted as 10 per 1000 in India or 4 per 1000 in China. It is also found to be the main causes of the heart failure due to the valvular heart diseases. ${ }^{2,3}$ While in Indonesia, rheumatic fever were count as 0,3-0,8 per 1000 school aged where the limited modalities for active screening programs can underestimate its prevalence within the adult population ${ }^{4}$ One study in high-volume cardiac centre in India found that from echocardiograms data within 2 years, $60.2 \%$ of RHD are found to be mitral stenosis (MS), followed by aortic stenosis (AS), and tricuspid and pulmonal problem. ${ }^{5}$ To be dated, it is estimated that there are over 15 million cases of RHD worldwide, with 282.000 new cases, ad 233.000 deaths annualy. ${ }^{6}$ 
Echocardiography has become the key tool for the diagnosis and evaluation and for clinical decision-making of valve stenosis. For MS, some parameters such as mean gradient, mitral valve area by planimetry and by pressure half time are being the Level I recommendations, followed by continuity equation, PISA and mitral valve resistance on the Level II and III. ${ }^{1}$ Those echocardiography modalities are completing each other especially when discrepancies between other parameters are found. Unfortunately, most of them are using an advance echocardiography modalities such as Doppler (continuous and pulsed wave) that are only available mostly in sophisticated centres, not in the rural health centers of the most of developing country. Confirming mitral valve area (MVA) by planimetry will significantly help the initial management and definitive therapy as well.

Both continuous and pulsed wave doppler display time, direction, and velocity at a single location which is depicted by the cursor or sample volume position and a simple color Doppler M-mode is shared the same concepts. By placing the M-mode cursor along the path of transmitral inflow, color Doppler M-mode is able to display intracavitary pressure gradients of mitral flow a transmitral flow propagation velocity $(\mathrm{Vp})^{7,8}$

In case of MS, the propagation of blood through the narrow valve towards the ventricular apex must have a different velocity and flow dynamic compared to the normal mitral valve. ${ }^{9}$ The narrower the mitral valve is, the more difference on the dynamic flow can be found. We suggest that this new hemodynamic condition regarding pressure and flow through the stenotic mitral will have a pattern related to its severity.

Our aim was to evaluate the significance of a simple mitral inflow color M-mode velocity propagation (Vp) for estimating mitral stenosis severity and mitral valve area by making use of the high temporal resolution of $\mathrm{M}$-mode to examine the progression of mitral inflow through the stenotic valve.

\section{METHODS}

This study were included patients with MS aged 18-60 years old that consulted to have echocardiography examination in Non Invasive Division of Haji Adam Malik Hospital Medan from October until December 2017. All patients gave informed consent. Those with severe aortic valve disease, severe mitral regurgitation, previous cardiac surgery patients, patients who had prosthetics valves, existence of congenital valve stenosis, left ventricle hypertrophy, NYHA class III-IV heart failure and/or left ventricular systolic dysfunction (LVEF $\leq 35 \%$ ), as well as those with a history of ASD, VSD, or PDA were excluded.

All patients will have a complete 2D transthoracic echocardiographic and Doppler study from multiple windows. Studies were performed using the Vivid-7 system (General Electric) and Medison Accuvix V10 (Samsung) with $2.5 \mathrm{MHz}$ transducer. The gain, depth, sector angles and nyquist limit ranges were adjusted as needed for each case and zoom mode was used where necessary.

This study were performed with the patients at rest (heart rate of $60-100$ beat per minute) with 2D echocardiographic measurements were obtained in the parasternal long axis, short axis and apical four-chamber views. The measurements acquired were as follows: mitral valve area (MVA) according to planimetry, transmitral mean gradient, pressure half-time (PHT), estimated systolic pulmonary artery pressure (PASP) and mitral color M-mode flow propagation velocity $(V p)$, left ventricular systolic function by Teicholz, left ventricular end-diastolic, and Tricuspid 
Annular Plane Systoloc Excursion (TAPSE). Echocardiographic measurements were performed in accordance with the guidelines issued by The American Society of Echocardiography. The Vp value was obtained from $2 \mathrm{D}$ apical fourchamber echocardiographic images using Doppler color flow imaging and M-mode method.

The M-mode scan line was oriented along the center-line of inflow, from the mitral valve towards the apex. Before the color M-mode Doppler measurement, the Nyquist limit and color gain of the equipment were adjusted for aliasing (until the central jet with the highest velocity was seen as blue) by shifting the color baseline in the direction of flow to the apex.

$\mathrm{Vp}$ was determined by measuring the slope of the blue jet with the first aliasing velocity formed during early diastole which is signed by the slope along the first clearly demarcated isovelocity contour and identified by the first color transition interface. ${ }^{7,8}$ In patients with sinus rhythm, we averaged at least 3 cardiac cycles, while in those with atrial fibrillation at least 5 cardiac cycles were averaged. Investigators are blindly performed the quantitative echocardiographic grading of MS and the Vp as well.

This study set at alpha 0.05 with minimal AUC at 0.70 with $80 \%$ power. Obtained data were analyzed using the SPSS 21.0 software package for Windows. Continuous variables were presented as mean \pm standard deviation and frequency by percentages. Correlation between mitral $\mathrm{M}$-mode flow propagation velocity $(\mathrm{Vp})$ and severity of MS analyzed by Pearson correlation and the difference were compared by $\mathrm{T}$ independent test. Reference measurements for $\mathrm{Vp}$ were planimetry and $\mathrm{PHT}$; ROC analysis was performed with a 95\% confidence interval. The threshold of significance for all hypotheses was set at $p<0.05$.

\section{RESULTS}

Thirty one MS patients were undergone transthoracic echocardiography with MVA planimetry average $0.99 \pm 0.35$ $\mathrm{cm}^{2}$ and mean Vp $64.49 \pm 21.63 \mathrm{~cm} / \mathrm{s}$. Most of patients have mean PASP of $55.67 \pm 19.36 \mathrm{mmHg}$ with good RV function as mean TAPSE $17.26 \pm 1.91$ and good LV function as well, with mean ejection fraction of $61.19 \pm 5.6 \%$.

The $\mathrm{Vp}$ has been found to have a strong negative correlation with the MVA (Spearman rho -0.865, $\mathrm{p}<0.01$ ). By confirming to the MVA by planimetry, ROC Analysis found that $V p$ have a significant discrimination power (AUC 0.931, p value $<0.001)$ to differ severe mitral stenosis to mild-moderate mitral stenosis with cut off value of $55 \mathrm{~cm} / \mathrm{sec}$. We simply estimated MVA by multiplying the divided $\mathrm{Vp}$ from alliasing velocity by 1.5 for $V p$ 's role to explain MVA is significant $\left(R^{2} 0.504\right.$, $p<0.01$ ) (Figure 2B).

The estimation of MVA by Vp was found not significantly different with MVA by planimetry from the one sample T-test ( $p$ value 0.274), and no proportional bias were found as also seen from the Bland Altman scatter plot showing a good level of agreement between the two measurements with a bias of $-0.0471 \pm$ $0.4508(p=0.567)$ (Figure 3). Vp were also been found to have a moderate correlation with MVA by PHT ( $r-0.62, p<0.01)$.

\section{DISCUSSIONS}

Some studies have previously shown that Mitral color M-Mode $\mathrm{Vp}$ of mitral flow propagation toward the ventricle was a useful index for the assessment of left ventricular diastolic function. ${ }^{1}$ In case of MS, the pressure gradient created between the ventricle and atrium generates the driving force causing flow to 


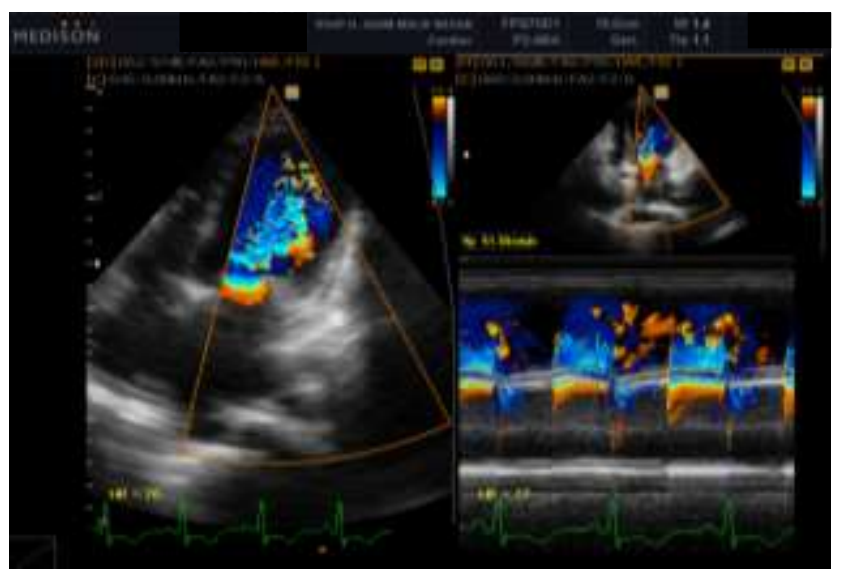

Figure 1. Severe mitral stenosis as the slope of the first aliasing velocity from the mitral valve to LV cavity

Table 1. Baseline Characteristics

\begin{tabular}{lc}
\hline \multicolumn{1}{c}{ Parameter } & Total \\
\hline Age (years \pm SD) & $43.65 \pm 10.12$ \\
Female (\%) & 54.8 \\
MVA by Planimetry (cm² \pm SD) & $0.99 \pm 0.355$ \\
PHT (ms \pm SD) & $300.7 \pm 114.62$ \\
Mean PG (mmHg) & $9.8 \pm 4.26$ \\
LVEDD (mm \pm SD) & $46.22 \pm 4.2$ \\
EF (\% \pm SD) & $61.19 \pm 5.6$ \\
PASP ( mmHg \pm SD) & $55.67 \pm 19.36$ \\
TAPSE (mm \pm SD) & $17.25 \pm 1.91$ \\
Vp (cm/s \pm SD) & $64.49 \pm 21.63$ \\
\hline
\end{tabular}

MVA: Mitral Valve Area; PHT: Pressure Half Time; PG: Pressure Gradient; LVEDD: Left Ventricle End Diastolic Diameter; EF: Ejection Fraction; PASP: Pulmonary Arterial Systolic Pressure; TAPSE: Trans Annular Plane Systolic Excursion; Vp: Velocity Propagation.
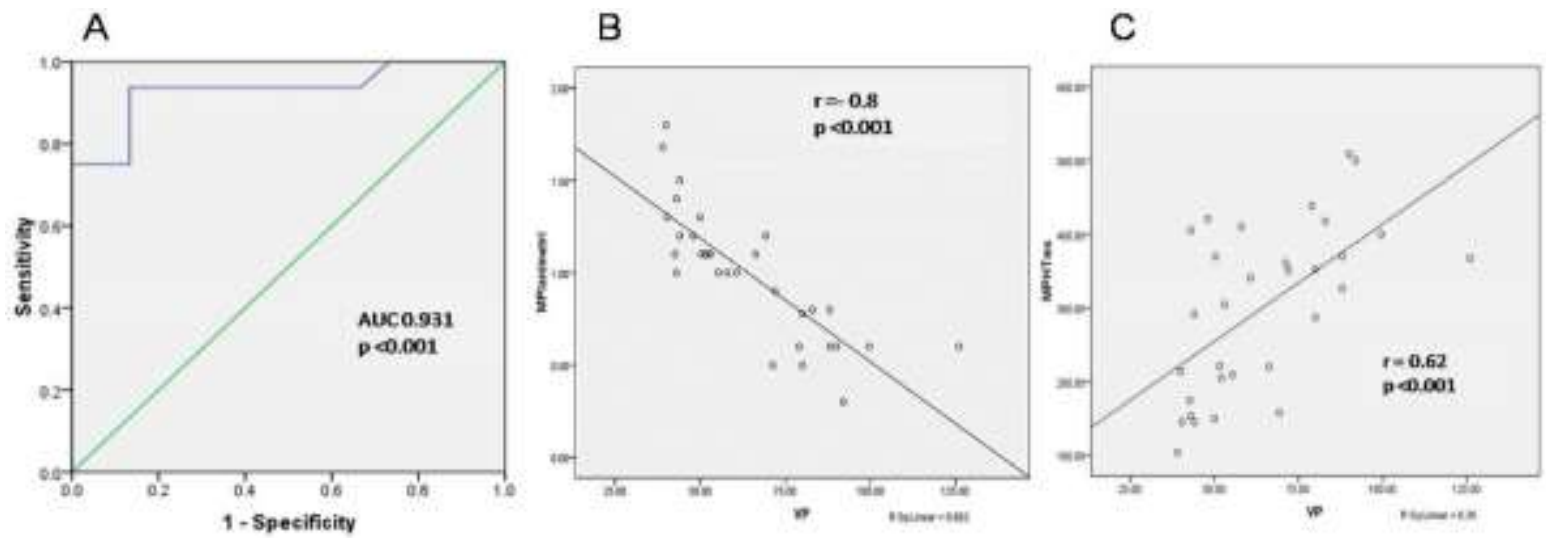

Figure 2.A. ROC Curve of Vp to differentiate severe to mild-moderate mitral stenosis, B. Scatter plot showing strong negative correlation of $\mathrm{Vp}$ and MVA by planimetry $\left(\mathrm{cm}^{2}\right)$ and $\mathbf{C}$. moderate positive correlation of $\mathrm{Vp}$ and MVA by PHT (ms) 
Table 2. Diagnostic test of Vp for Severe Mitral Stenosis

\begin{tabular}{llllll}
\hline $\begin{array}{l}\text { Vp } \\
(\mathbf{c m} / \mathbf{s})\end{array}$ & $\begin{array}{l}\text { Sensitivity } \\
(\%)\end{array}$ & $\begin{array}{l}\text { Specificity } \\
(\%)\end{array}$ & $\begin{array}{l}\text { Negative Predictive } \\
\text { Value (\%) }\end{array}$ & $\begin{array}{l}\text { Positive Predictive } \\
\text { Value (\%) }\end{array}$ & $\begin{array}{l}\mathbf{p} \\
\text { value }\end{array}$ \\
\hline$>55$ & 93.8 & 86.7 & 92 & 88 & $<0.001$ \\
\hline
\end{tabular}

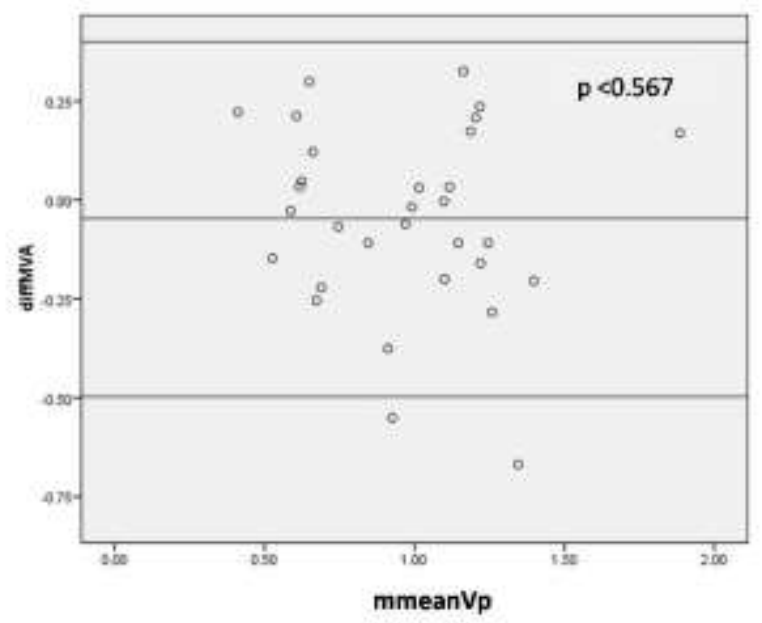

Figure 3. The Bland Altman Plot showing no proportional bias of mean difference from two measurements.

propagate from mitral orifice toward the left ventricle. The more stenosis the valve is, there must be the faster flow velocity at the level of the mitral valve in the setting of a good left ventricle function. If the flow velocity at the stenosis mitral level is increasing, so based on the simplified Bernoulli Law, there will be an increasing on the pressure gradient at that point as well. The ability of M-mode considering that pressure gradients can be used, as the $\mathrm{Vp}$ also described it by the first isovelocity line on the early diastolic at level of that stenosis mitral. This study found that $V p$ has a strong negative correlation with the MVA by planimetry, with the statistically significant discrimination power as seen from the AUC of 0.931 with the high sensitivity for differentiating severe to mild-moderate mitral stenosis. This study were mainly compared the Vp with MVA by the planimetry which mitral valve area were traced at the level of the mitral annulus. ${ }^{1,7}$ furthermore, we use the Duval-Moulin Garcia for the easiest and probably most commonly employed method used to measure $\mathrm{Vp}$. This method has the advantage of not being dependent on any particular 2 pixels or points for determining the $\mathrm{Vp}$ line, unlike the Stugaard and the Takatsuji methods for the continuous line formed more clear in this method. As a result, the Garcia method had more consistent $\mathrm{Vp}$ fits for almost all the patients examined. ${ }^{7,10}$

A good left ventricle function in MS will have a good suction and relaxation effect of left ventricle on the diastolic phase. Thus, Vp can be used in this study, 
for the diastolic function in MS is preserved. Therefore, the likelihood of the other confounding factor were absent as no diastolic dysfunction in this study were found. The usefulness of $\mathrm{Vp}$ other than diastolic function was seen also in another valve assessment, such as for the mitral regurgitation, or aortic regurgitation. The similar concept of $\mathrm{Vp}$ in the regurgitation valve was the regurgitate volume would go to the area with the lower pressure, thus the direction and velocity of flow could be determined.

The previous study about $\mathrm{Vp}$ in MS was conducted by Sari and found to have a same conclusion with this study. ${ }^{9-12}$ On this study, $\mathrm{Vp}$ were also had a good correlation with PHT, which confirm the significance of M-mode on describing the relationships of time, direction, and velocity for the pressure gradient on two chambers. ${ }^{7}$ Other study also found that $\mathrm{Vp}$ had a relationships with pulmonary vascular resistance and wedge pressure. $^{13,14}$

At a same second, flow volumes that passing through mitral by the active recoil and relaxation of LV will have an equal amount with the flow that reach the basis of LV. The simple physics law says that flow rate is equal to velocity multiplied by surface area. If we consider the viscosity, angle and the distance of flow within the LV is constant, we can estimate the valve area of the passed mitral.

The flow velocity higher than the aliasing velocity could be displayed in blue within red filling flow signals. ${ }^{15}$ If the nyquist limit and aliasing velocity we set from the color baseline is the minimal velocity that can be read by Doppler as a minimal isovelocity, so the minimal velocity at the point of the mitral will around the same with the aliasing velocity, whereas the highest flow propagation will be described by the Vp. By that, we can predict the moderate-severe MS from the mild MS (MVA more than 1.5) if the assumption is the minimal isovelocity that we set will pass the mild stenosis. So, for distinguishing the moderate-severe stenosis, there were made formula that the multiplication of $\mathrm{Vp}$ with the actual stenotic mitral valve will be equal to the multiplication of aliasing velocity by 1.5 . Thus, MVA can be estimated by the means of Vp. In this study, the MVA calculated by $\mathrm{Vp}$ is not significantly different by the MVA traced by planimetry, as was proved by one sample $\mathrm{T}$ test and Bland Altman plot ( $p$ value $>005$ )

This study findings will be useful for helping the severity of MS, especially on the limited imaging modalities healthcare as we had in Indonesia, where the program installed in the echo machine could be limited as well, probably too basic and not completed with doppler. This will affect the initial management for both pharmacological and definitive and indeed helpful on define the goal therapy on the severe MS. Beside the echo facilities availabilities, Vp could also be a supporting modalities for MS when discrepant occurred resulted by the weakness of other standard echo modalities. The MVA planimetry can be biased by the heavy calcification, or even by the poor acoustic window for this assessment was so operator dependent and highly influenced by experience. Meanwhile, the mean gradient was also influenced by flow and heart rate.

This study was focused at the mitral stenosis assessment and thus the comparison with the normal valve was not included. With the correct initial assessment, the proper diagnosis can be made even by as simple modalities as 2D echocardiography especially when the stenosis severity was not really clear yet. This study was very possible to be grown with the larger sample size, besides no further analysis or subgroup analysis and multivariate analysis conducted for confirming how far the effect of other 
concomitant heart structural condition (regurgitation) to $\mathrm{Vp}$ on grading the $\mathrm{MS}$ severity.

Later on, interpretation of $\mathrm{Vp}$ values can be vary depend on the methods used and erroneous measurements due to angulation between M-mode cursor and flow had to be considered. This study only involved the stenotic mitral to see the correlation of $\mathrm{Vp}$ and the MVA so it is not designed to have $\mathrm{Vp}$ distinguish the normal and stenotic mitral. $\mathrm{Vp}$ in this study is only used within the stenotic mitral only.

\section{CONCLUSION}

\begin{abstract}
A simple Mitral M-Mode Vp (Velocity Propagation) were found statistically significant for estimating severity and mitral valve area in MS. Interventional decision for MS could also considered $\mathrm{Vp}$ for its strong correlation with MVA on MS and this were found to be helpful for rural and limited centers for targeting moderate to severe MS and for better initial management and goal therapy, considering the high prevalence of $\mathrm{RHD}$ in our working area.
\end{abstract}

\section{ACKNOWLEDGEMENT}

Authors acknowledge these following persons: dr. Rian Apriza, dr. Yosua Cristo $\mathrm{N}$, Ns. Esti Suryani Napitupulu, dr. Chai SH, dr. Nizam Zikri Akbar, Sp.JP(K), Andre Pasha Ketaren, Sp.JP(K), Ali Nafiah Nasution, Sp.JP(K), T. Bob Haykal, Sp.JP(K), Zulfikri Mukhtar, $\operatorname{Sp.JP}(K)$

\section{REFERENCES}

1. Baumgartner H., Hung J., Bermejo J., Chambers J.B., Evangelista A., Griffin B.P., et al. 2009. Echocardiographic assessment of valve stenosis: EAE/ASE Recommendations for clinical practice. J Am Soc Echocardiogr, 22:1-23.

2. Ranjan R., Pressman G.S. 2018. Aetiology and epidemiology of mitral stenosis. E-Journal of Cardiology Practice. 16(14), accessed 2018 September on https://www.escardio.org/Journals/EJournal-of-CardiologyPractice/Volume16/Aetiology-andepidemiology-of-mitral-stenosis

3. Seckeler M.D., Hoke T.R. 2011. The worldwide epidemiology of acute rheumatic fever and rheumatic heart disease. Clin Epidemiol, 3:67-84.

4. Siregar A.A. 2008. Demam rematik dan penyakit jantung rematik permasalahan Indonesia. Pidato Pengukuhan Jabatan Guru Besar Tetap pada Fakultas Kedokteran. 2008. USU Repository

5. Manjunath C.N., Srinivas P., Ravindranath K.S., Dhanalakshmi C. 2014. Incidence and patterns of valvular heart disease in a tertiary care high-volume cardiac center: A single center experience. Indian Heart J, 66:320-326.

6. Carapetis J.R., Steer A.C., Mulholland E.K., Weber M. 2005. The global burden of group A streptococcal diseases. Lancet Infect Dis.5:685-694.

7. Bonita A. 2007. Chapter 15: Doppler assessment of left ventricular diastolic function on Echocardiography: The Normal Examination and Echocardiographic Measurements $2^{\text {nd }}$ Edition. MGA Graphics, pp. 283-290.

8. Solomon S.D. 2007. Chapter 6: Echocardiographic assessment of diastolic dysfunction on Essential Echocardiography. Humana Press Inc., pp. 120-130.

9. Sari M. 2016. Color M-mode mitral propagation velocity in patients with mitral stenosis. Journal of Human Rhythm, 2:46-52.

10. Sessoms M.W., Lisauskas J., Kovács S.J. 2002. The left ventricular color M- 
mode doppler flow propagation velocity $\mathrm{V}(\mathrm{p})$ : in vivo comparison of alternative methods including physiologic implications. $\mathrm{J}$ Am Soc Echocardiogr, 15:339-348.

11. Onbasili O.A., Tekten T., Ceyhan C., Ercan E., Mutlu B. 2002. A new echocardiographic method for the assessment of the severity of aortic regurgitation: Color M-mode flow propagation velocity. $\mathrm{J} \quad \mathrm{Am}$ SocEchocardiogr, 15:1453-1460.

12. Akdemir R., Ozhan H., Bulur S., Unlu H., Gunduz H., Arinc H., et al. 2005. Color M-mode regurgitant flow propagation velocity: A new echocardiographic method for grading of mitral regurgitation. Echocardiography, 22:713-722.

13. Lindqvist P., Söderberg S., Gonzalez M.C., Tossavainen E., Henein M.Y.
2011. Echocardiography based estimation of pulmonary vascular resistance in patients with pulmonary hypertension: a simultaneous Doppler echocardiography and cardiac catheterization study. EurJ Echocardiogr, 12:961-966.

14. Seo Y., Ishimitsu T., Ishizu T., Obara K., Moriyama N., Kawano S., et al. 2004. Assessment of propagation velocity by contrast echocardiography for standardization of color doppler propagation velocity measurements.JAmSocEchocardiogr, 17:1266-1269.

15. Kitabatake A. 1998..Propagation velocity of left ventricular filling flow measured by color m-mode doppler echocardiography. J Am Coll Cardiol, 31:1440-1448. 